\title{
Secretion of Calcitonin in Hypocalcemic States in Man
}

\author{
Leonard J. Deftos, David Powell, Jacqueline G. Parthemore, and \\ JoHN T. PotTs, JR. \\ From the Department of Medicine (Endocrinology), University of California, \\ San Diego, School of Medicine and Veterans Administration Hospital, \\ La Jolla, California 92161 and Endocrine Unit, Massachusetts General \\ Hospital, Boston, Massachusetts 02114
}

\begin{abstract}
A B S T RACT The control of calcitonin secretion in humans has been studied extensively only in patients with medullary thyroid carcinoma since the peripheral concentration of the hormone in normal subjects is too low for accurate measurement by existing assay procedures. However, we have recently found that the concentrations of calcitonin in the peripheral plasma of hypocalcemic subjects during provocative tests of hormone secretion were high enough to be measured by radioimmunoassay. Accordingly, the effect of calcium and pentagastrin infusions on plasma calcitonin was studied in nine patients with pseudohypoparathyroidism, seven patients with idiopathic hypoparathyroidism, and six patients with hypocalcemia not due to parathyroid disease. The infusion of calcium in these hypocalcemic subjects resulted in increases in plasma calcitonin to levels that could be readily detected by our radioimmunoassay. Pentagastrin infusion also caused an increase of plasma calcitonin in some subjects, but calcium was approximately 10 times more effective than gastrin in its stimulatory effect on hormone secretion. These results demonstrate that in humans as well as other mammals the secretion of calcitonin by parafollicular cells that are not involved by medullary thyroid carcinoma is directly related to plasma calcium and that gastrin can also stimulate hormone secretion. The results are consistent with the thesis that the secretion of calcitonin by normal human subjects does occur but at peripheral concentrations of the hormone below the detection limits of most existing immunoassays ; hypocalcemia leads to increased stores of hormone that can be released by the appropriate stimuli.
\end{abstract}

\section{INTRODUCTION}

The control of secretion of calcitonin in humans has been extensively studied only in patients with medullary

Received for publication 3 March 1973 and in revised form 23 July 1973.

The Journal of Clinical Investigation Volume 52 December 1973·3109-3114 thyroid carcinoma. These patients have peripheral concentrations of the peptide that are abnormally high and that can be readily measured by specific radioimmunoassays (1-3). In these patients, it has been shown during functional tests of hormone secretion that calcitonin levels are directly related to blood calcium: hormone concentration rises after induced hypercalcemia (calcium infusion) and falls after induced hypocalcemia (EDTA infusion) (2-4). The infusion of gastrointestinal hormones such as gastrin and glucagon, effective in stimulating calcitonin secretion in animal species (5-7), has a variable effect on calcitonin secretion in patients with this thyroid tumor $(2-4,8)$. Efforts to study calcitonin secretion in humans other than those with this thyroid cancer have not been extensive because peripheral calcitonin concentrations are too low for accurate measurement, even after calcium infusion $(4,9,10)$. We recently observed that, in contrast to findings in normal or hypercalcemic subjects, calcitonin levels after calcium infusion were high enough to be readily measured in patients with hypocalcemia due to various disorders (11). These patients were, therefore, studied in greater detail as they seemed to represent a unique opportunity to examine calcitonin secretion in subjects with parafollicular cells that are presumably free of medullary thyroid carcinoma.

\section{METHODS}

Three groups of patients with hypocalcemia were studied, patients with pseudohypoparathyroidism, patients with idiopathic hypoparathyroidism, and patients with hypocalcemia not due to relative or absolute parathyroid hormone deficiency, many of whom had clinical evidence of malabsorptive states (12). The patients with pseudohypoparathyroidism had hyperphosphatemia in addition to hypocalcemia, the classical somatotype of pseudohypoparathyroidism, and elevated levels of immunoassayable parathyroid hormone (13). The patients with idiopathic hypoparathyroidism also had hyperphosphatemia in addition to the hypocalcemia but were without the characteristic somatotypic features of pseudo- 
parathyroidism, and immunoreactive parathyroid hormone was not detected in their plasma. The third group of patients with hypocalcemia had either hypophosphatemia or normophosphatemia and normal or elevated levels of parathyroid hormone (Table I). All patients had normal renal function.

Fasting plasma samples were collected from each patient. Each patient also underwent a calcium infusion of 5 $\mathrm{mg} / \mathrm{kg}$ per $\mathrm{h}$ of calcium as calcium chloride for a total of $3 \mathrm{~h}$ except in one instance. In that one patient (represented by the symbol $\downarrow$ in Fig. 4), the infusion was terminated at $2 \mathrm{~h}$ because of infiltration. 10 patients with hypercalcemia and 10 normal subjects served as comparison groups for the calcium infusions. In addition, pentagastrin (Peptavlon, Ayerst Laboratories, N. Y., N. Y.) at a dose of $0.5 \mu \mathrm{g} / \mathrm{kg}$ was given intravenously over several minutes to seven of the patients. In these seven patients who received calcium and gastrin infusion, both infusions were performed within 1 wk of each other. The patients were not treated for their hypocalcemia between the two infusions, and there was no significant difference in the basal plasma calcium at the start of the calcium and gastrin infusion for each patient, respectively. In three of the patients (Fig. $4, \bullet, \square, \boldsymbol{\Delta}$ ) the calcium infusion preceded the gastrin infusion; in the remaining four $(\Delta, \boldsymbol{\square}, \Delta, 0)$, the gastrin infusion preceded the calcium infusion. Heparinized plasma samples were collected for measurement of calcium and calcitonin before each infusion and at $1,2,3$, and $4 \mathrm{~h}$ after the beginning of the calcium infusion and $\frac{1}{2}, 1,2,3$, and $4 \mathrm{~h}$ after the beginning of the gastrin infusion. Calcium was measured by atomic absorption spec- trophotometry. Plasma calcitonin was measured by radioimmunoassay $(4,14)$. Each plasma sample was assayed in at least two assays and at multiple dilutions ranging from $25,50,75$, and $100 \mu \mathrm{l}$ in a final incubation volume of $500 \mu \mathrm{l}$. In all instances, related samples, such as the comparison of the effect on calcitonin of gastrin and calcium infusions, were run in the same assay. In our experience with the immunoassay for calcitonin most normal and hypercalcemic subjects have undetectable (less than $100 \mathrm{pg}$ per $\mathrm{ml}$ ) levels of hormone even after calcium infusion $(4,14)$, and the inter- and intra-assay variation is 20 and $10 \%$, respectively.

\section{RESULTS}

The mean $( \pm \mathrm{SE}$ ) basal plasma calcium for all of the hypocalcemic subjects was $7.02( \pm 0.32) \mathrm{mg}$ per 100 $\mathrm{ml}$. The plasma calcium and parathyroid hormone for each of the three subgroups is tabulated in Table I. Fig. 1 shows a typical result of the effect of calcium infusion on plasma calcitonin in a patient from each one of the three hypocalcemic groups. Fig. 2 summarizes the effects of calcium infusion on plasma calcitonin for all of the subjects. In this figure the highest plasma calcitonin after the start of the calcium infusion is plotted for each patient. In each case except one, the calcitonin value was the one taken at $3 \mathrm{~h}$, the end of the infusion. In one patient, the $2-\mathrm{h}$ value is
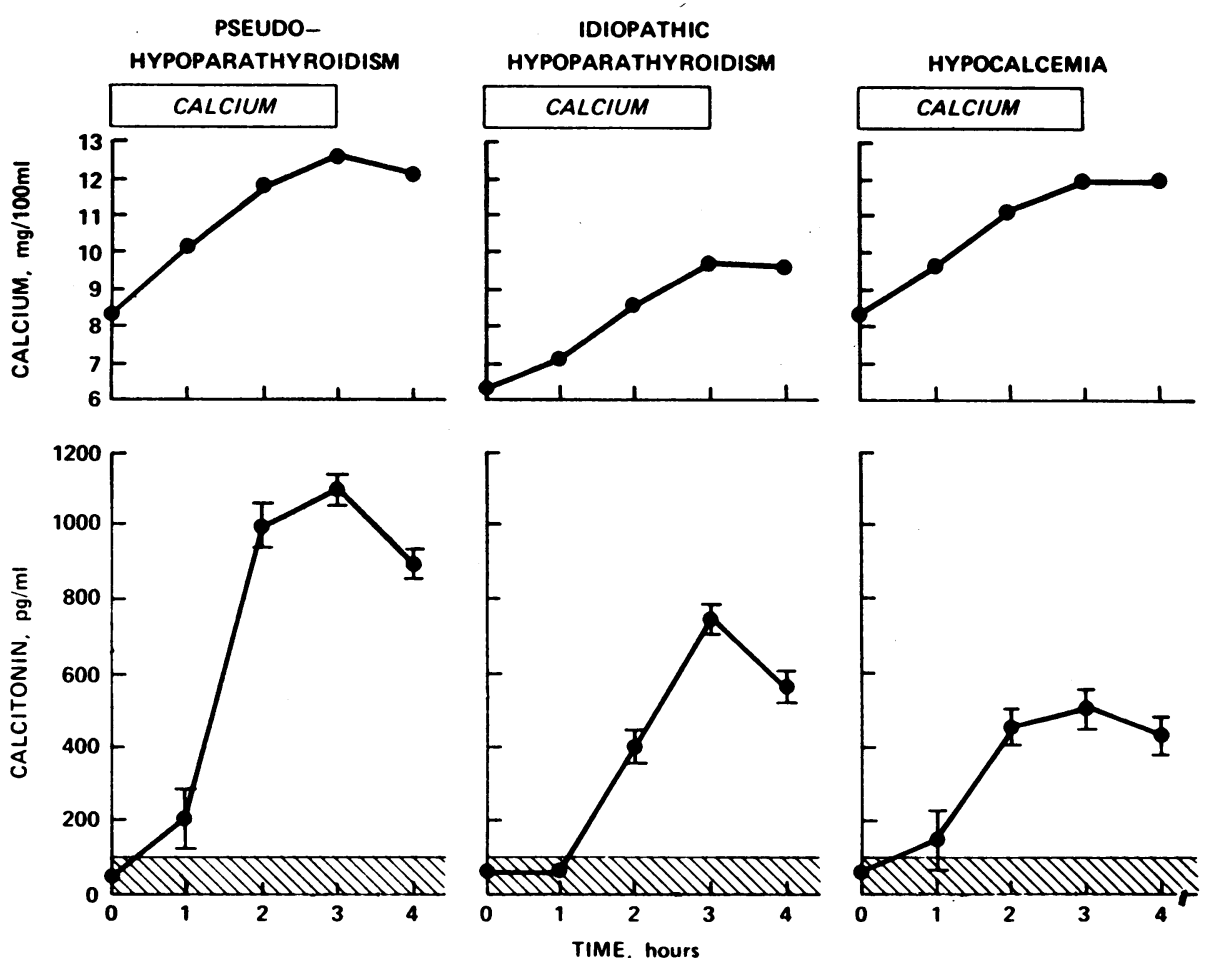

FIGURE 1 Effect of calcium infusion on plasma calcitonin in three hypocalcemic patients. In each subject there was a marked increase in plasma calcitonin. Shaded area represents calcitonin values below the detection limits of the radioimmunoassay. 
TABLE I

Mean $( \pm \mathrm{SE})$ Concentration of Plasma Calcium and Immunoassayable Purathyroid Hormone (PTH) in three Groups of Hypocalcemia Subjects

\begin{tabular}{|c|c|c|c|}
\hline Patients & no. & PTH* & Calcium \\
\hline Pseudohypoparathyroidism & 9 & $\begin{array}{c}n g \text { per } m l \\
1.55 \\
( \pm 0.29)\end{array}$ & $\begin{array}{c}m g \text { per } 100 \mathrm{ml} \\
7.71 \\
( \pm 0.42)\end{array}$ \\
\hline Idiopathic hypoparathyroidism & 7 & $<0.10$ & $\begin{array}{c}6.28 \\
( \pm 0.55)\end{array}$ \\
\hline Hypocalcemia not due to parathyroid disease & 6 & $\begin{array}{c}0.758 \\
( \pm 0.170)\end{array}$ & $\begin{array}{c}6.86 \\
( \pm 0.65)\end{array}$ \\
\hline
\end{tabular}

* Normal mean ( $\pm \mathrm{SE})$ PTH: $0.56( \pm 0.08) \mathrm{ng}$ per $\mathrm{ml}$ (range $0.3-0.8 \mathrm{ng} / \mathrm{ml})$.

$\ddagger$ Normal calcium range : $8.5-10.5 \mathrm{mg}$ per $100 \mathrm{ml}$.

plotted since the infusion was terminated at this time because of infiltration. Calcium infusion was followed by an increase in plasma calcitonin in the majority of the hypocalcemic subjects. There was no definite increase in plasma calcitonin in the control group of normal and hypercalcemic subjects. Among the individual patients, no correlation could be established between the postinfusion plasma calcitonin and either the basal calcium or parathyroid hormone concentration, the postinfusion calcium, or the change in calcium

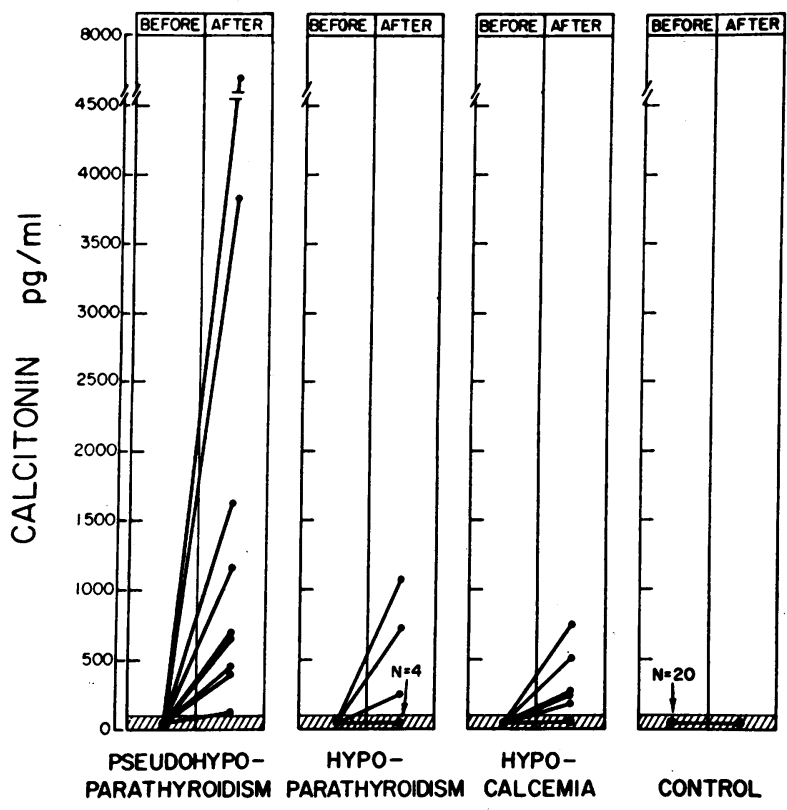

FIgURE 2 Plasma calcitonin after calcium infusion in 22 patients with hypocalcemia and in 20 control subjects. For each subject, the maximum calcitonin response is plotted. This occurred at the end of the $3-\mathrm{h}$ infusion in each instance except one (represented by 7,000 pg per $\mathrm{ml}$ ) in which the infusion was terminated at $2 \mathrm{~h}$. Shaded area represents detection limits of assay. during infusion. That is to say, the patients who exhibited the greatest post-calcium concentration of plasma calcitonin did not necessarily have the lowest basal calcium or parathyroid hormone concentration nor did they necessarily experience the greatest increase in blood calcium during the infusion. However, the greatest mean increase in plasma calcitonin occurred in the patients with pseudohypoparathyroidism, and

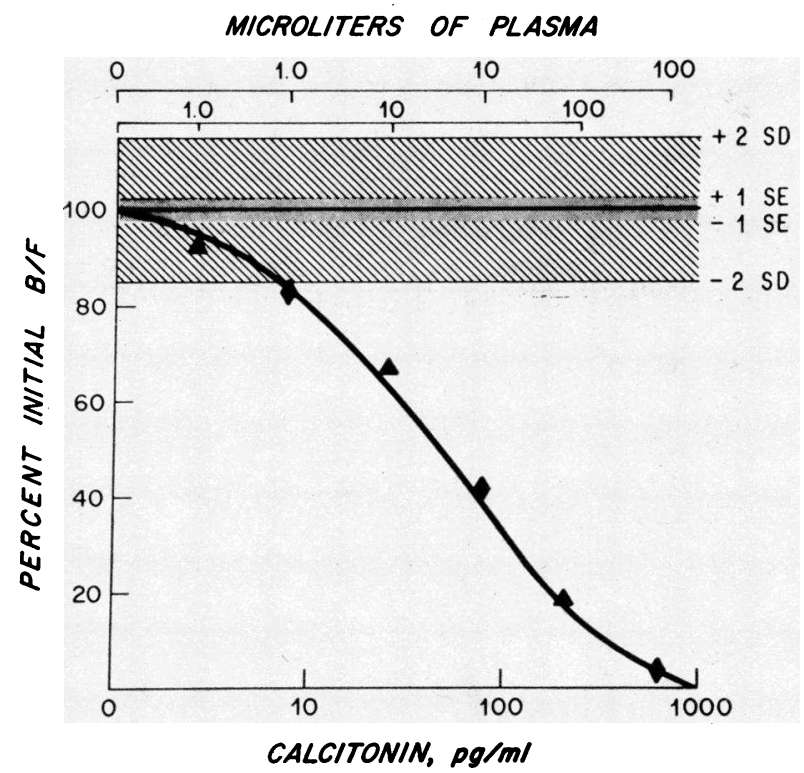

FIGURE 3 Comparison of the displacement of ${ }^{125}$ I-labeled calcitonin from specific antibody produced by increasing aliquots of calcitonin standard (curved line) and postcalcium infusion plasma from two patients with hypocalcemia, one with pseudohypoparathyroidism and one with idiopathic hypoparathyroidism. The standard calcitonin and the plasma calcitonin were indistinguishable in their effects on the displacement of labeled calcitonin from antibody. Also shown in the shaded areas are the mean, standard error, and standard deviation from the zero point of the standard curve.

Calcitonin Secretion in Hypocalcemia 
this response was significantly greater $(P<0.01)$ than that which occurred in the other patients.

Fig. 3 compares the effect of the calcitonin in the postcalcium infusion plasma samples from two of the hypocalcemic subjects to the effect of the calcitonin standard on the inhibition of the binding of labeled calcitonin by specific antibody. The assay curve produced by dilutions of the plasma samples superimposed on that produced by the calcitonin standard. Similar results were obtained with corresponding samples from other hypocelcemic subjects.

Fig. 4 compares the effect of pentagastrin infusion to the effect of calcium infusion on plasma calcitonin in several hypocalcemic subjects who received both infusions. The highest postgastrin concentration of calcitonin is plotted in each instance. In contrast to the calcium infusion, there was more variability in response of calcitonin to gastrin with the peak concentration varying from $\frac{1}{2}$ to $2 \mathrm{~h}$ after gastrin infusion. Calcium infusion was followed by an increase in plasma calcitonin in all subjects except one (with idiopathic hypoparathyroidism) who also did not respond to the gastrin infusion. Three of the seven hypocalcemic subjects did not respond to pentagastrin infusion. Pentagastrin had no demonstrable effect on plasma calcium. As with the calcium infusion, no correlation could be established between the postgastrin concentration of calcitonin in the individual subjects and the other measured

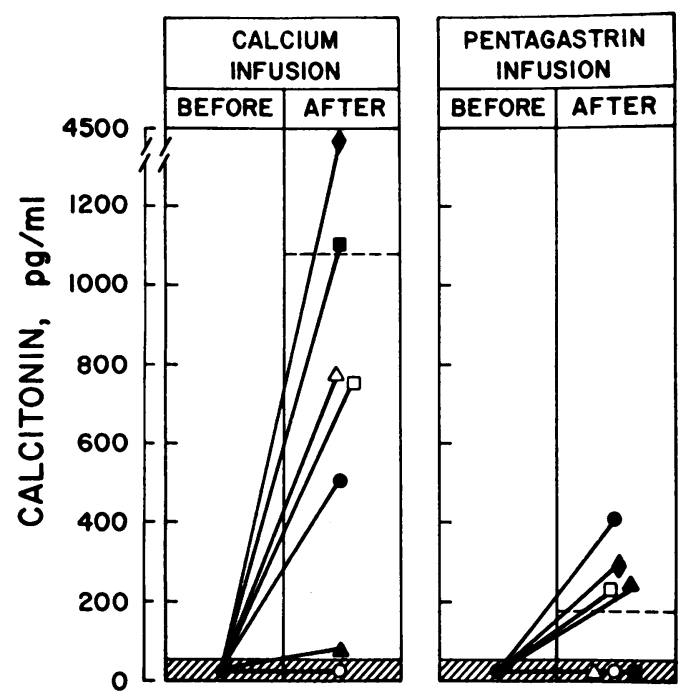

FIGURE 4 Comparison of the effect of pentagastrin infusion and calcium infusion on plasma calcitonin in seven hypocalcemic subjects (pseudohypoparathyroidism $\bullet, \triangle$; idiopathic hypoparathyroidism $\mathrm{O}, \boldsymbol{\Delta}, \boldsymbol{\square}$; and hypocalcemia $O, \square)$ who received both infusions. For each subject, the maximum calcitonin response is plotted. The mean plasma calcitonin (dashed line) after calcium infusion was 10 times greater than that seen after gastrin infusion. parameters. The mean plasma calcitonin (dashed lines) was 10 times greater after calcium infusion than gastrin infusion. If the stimulated plasma calcitonin values of the patient with the highest postcalcium calcitonin concentration $(\diamond)$ are not considered, the mean plasma calcitonin after calcium infusion is approximately four times that after gastrin infusion, still considerably greater.

\section{DISCUSSION}

Calcitonin has been measured by radioimmunoassay in the peripheral plasma of several animal species (5-7). Its concentration has been found to range from approximately 0.1 to $10.0 \mathrm{ng}$ per $\mathrm{ml}$, and a direct relationship has been established between plasma calcium and calcitonin secretion in these species (11-21). Calcitonin has also been readily measured by radioimmunoassay in the plasma of patients with medullary thyroid carcinoma; in some patients peripheral concentrations of hormone in excess of $10 \mathrm{ng}$ per $\mathrm{ml}$ have been reported (1-4). Furthermore, a direct relationship between calcitonin secretion and plasma calcium has also been demonstrated in these patients during calcium and EDTA infusions (2-4). However, considerable controversy exists about the measurement of calcitonin in subjects other than those with medullary thyroid carcinoma $(2-4,8,9,20)$. In an extensive group of normal and hypercalcemic subjects evaluated with our radioimmunoassay, basal plasma calcitonin was generally undetectable (less than $100 \mathrm{pg}$ per $\mathrm{ml}$ ), and calcium infusion did not result in the conclusive detection of circulating calcitonin $(4,14)$. However, in the present group of hypocalcemic subjects, calcium infusion had a marked effect on plasma calcitonin (Fig. 1). During calcium infusions plasma calcitonin became readily detectable in the peripheral plasma of the majority of such patients (Fig. 2). Furthermore, the levels of calcitonin after calcium challenge were as high as those seen in some patients with medullary thyroid carcinoma even after calcium infusion (14). Further studies of these patients seemed useful in order to examine the reasons for the difficulty in demonstrating circulating calcitonin in man, a situation markedly different from results found in other mammals (5-7, 12, $16-19,21$ ).

These studies further revealed that the calcitonin in the plasma samples from the hypocalcemic subjects who were given calcium and gastrin infusions was indistinguishable from the standard calcitonin preparation in its reactivity in the immunoassay (Fig. 3). Since the assay for human calcitonin is based on calcitonin isolated from medullary thyroid carcinoma, this observation indicates that the human calcitonin released into plasma from nonmalignant parafollicular cells is 
immunochemically indistinguishable in this particular assay system from that derived from malignant parafollicular cells (medullary thyroid carcinoma). This finding does not support the view that the difficulty in detecting calcitonin in normal human subjects is due to the fact that the calcitonin produced by normal human thyroid glands differed from calcitonin produced by malignant parafollicular cells so that the hormone from normal subjects cannot be measured immunologically by a radioimmunoassay based on human tumor calcitonin. The results obtained make it more likely that the difficulty in measuring calcitonin by radioimmunoassay in the plasma of patients other than those with medullary thyroid carcinoma results from the fact that the peptide circulates at concentrations at or below the detection limits of most radioimmunoassays for human calcitonin $(10,11)$. However, it is still possible that the calcitonin secreted by malignant parafollicular cells is different from that secreted by normal parafollicular cells. This difference might not be reflected in our assay system if the antibody reacts against a common structural region of the calcitonin molecule.

One possible explanation for the very high levels of plasma calcitonin seen in patients with hypocalcemia after calcium infusion is that the hypocalcemia in these subjects results in increased storage of calcitonin in the thyroid gland so that the induced hypercalcemia promotes the secretion of these increased stores into the circulation. Accordingly, the storage and secretion of calcitonin by the presumably normal parafollicular cells in these hypocalcemic subjects is influenced by plasma calcium in a manner similar to that demonstrated for calcitonin in patients with medullary thyroid carcinoma and in a variety of animal species. This view is supported by data in rats in which it has been shown that chronic hypocalcemia tends to increase thyroidal stores of calcitonin (22). Clearly, more sensitive assays are needed to detect secretion of calcitonin in normal human subjects; the present results in hypocalcemic subjects are only inferential with respect to calcitonin physiology in man but do provide the stimulus for further study of this problem.

The effect of gastrointestinal factors on calcitonin secretion has received recent attention. Both glucagon and pentagastrin have been shown to stimulate the secretion of calcitonin in animals (5-7). Although these gastrointestinal hormones have also been shown to stimulate calcitonin secretion in some patients with medullary thyroid carcinoma, their effect is not as consistent or as pronounced as calcium infusion (2$4,8,23)$. Furthermore, since pharmacological levels of gastrointestinal hormones have been used in most studies, the physiological importance of these hor- mones in regulating calcitonin secretion has not been established. In our studies, there was a slight increase in plasma calcitonin in four of seven subjects with hypocalcemia after the administration of a large dose of pentagastrin (Fig. 4). However, the effect of calcium infusion on plasma calcitonin was 10 times greater in these subjects than the effect of pentagastrin. It is not likely that this lesser response to gastrin was seen because the parafollicular cells had been depleted of calcitonin by calcium infusion. The two infusions were separated by $1 \mathrm{wk}$ and in four of the seven patients gastrin infusion preceded calcium infusion. Since such high doses of pentagastrin were used to demonstrate an effect on calcitonin secretion, it cannot be concluded that in those patients who responded this represented other than a pharmacological effect of gastrin on calcitonin secretion. It is pertinent to note in this respect that Sizemore, Go, Kaplan, Sanzenbacher, Holtermuller, and Arnaud have recently reported abnormally increased concentrations of calcitonin in patients with hypergastrinemia (20). Although a physiological role for gastrointestinal hormones in the control of secretion of calcitonin has been postulated, such an effect has not been established in humans.

\section{ACKNOWLEDGMENTS}

Skilled assistance was provided by Mrs. Mady Bullen and Mrs. Germaine Roberts.

This work was supported by grants from the U. S. Public Health Service, the American Cancer Society, and the Veterans Administration.

\section{REFERENCES}

1. Clark, M. B., P. G. H. Byfield, G. W. Boyd, and G. V. Foster. 1969. A radioimmunoassay for human calcitonin. Lancet. $2: 74$.

2. Tashjian, A. H., Jr., D. G. Howland, K. E. W. Melvin, and C. S. Hill, Jr. 1970. Immunoassay of human calcitonin. N. Engl. J. Med. 283 : 890.

3. Deftos, L. J., A. D. Goodman, K. Eagleman, and J. T. Potts, Jr. 1971. Suppression and stimulation of calcitonin secretion in medullary thyroid carcinoma. Metab. (Clin. Exp.). 20: 428 .

4. Deftos, L. J., A. E. Bury, J. F. Habener, F. R. Singer, and J. T. Potts, Jr. 1971. Immunoassay for human calcitonin. II. Clinical studies. Metab. (Clin. Exp.). 20: 1129.

5. Cooper, C. W., L. J. Deftos, and J. T. Potts, Jr. 1971. Direct measurement of in vivo secretion of pig thyrocalcitonin by radioimmunoassay. Endocrinology. 88: 747.

6. Cooper, C. W., W. H. Schwesinger, A. M. Mahgoub, and D. A. Ontjes. 1971. Thyrocalcitonin: stimulation of secretion by pentagastrin. Science (Wash. D. C.). $172: 1238$.

7. Care, A. D., R. F. L. Bates, M. Phillippo, R. M. LeQuin, W. H. L. Hackeng, J. P. Barlet, and P. Larvor. 1970. Stimulation of calcitonin release from bovine thyroid by calcium and glucagon. J. Endocrinol. 48: 667.

8. Melvin, K. E. W., A. H. Tashjian, Jr., and H. Miller. 
1972. Studies in familial medullary thyroid carcinoma. Recent Prog. Horm. Res. 28: 399.

9. Melvin, K. E. W., H. H. Miller, and A. H. Tashjian, Jr. 1971. Early diagnosis of medullary carcinoma of the thyroid gland by means of calcitonin assay. $N$. Engl. J. Med. 285: 1115.

10. MacIntyre, I., G. V. Foster, J. Y. Woodhouse, P. Bordier, T. V. Gudmundsson, and G. F. Joplin. 1972. Calcitonin in man. In Calcium, Parathyroid Hormone and the Calcitonins, Proceedings of the Fourth Parathyroid Conference. R. V. Talmage and P. L. Munson, editors. Excerpta Medica Foundation, Publishers, Amsterdam. 83.

11. Deftos, L. J., T. M. Murray, D. Powell, J. F. Habener, F. R. Singer, G. P. Mayer, and J. T. Potts, Jr. 1972. Radioimmunoassays for parathyroid hormones and calcitonins. In Calcium, Parathyroid Hormone and the Calcitonins, Proceedings of the Fourth Parathyroid Conference. R. V. Talmage and P. L. Munson, editors. Excerpta Medica Foundation, Publishers, Amsterdam. 140.

12. Potts, J. T., Jr., and L. J. Deftos. 1973. Parathyroid hormone, thyrocalcitonin, vitamin $\mathrm{D}$ and diseases of bone and bone mineral metabolism. In Duncan's Diseases of Metabolism. P. K. Bondy, editor. W. B. Saunders Company, Philadelphia. 7th edition. In press.

13. Potts, J. T., Jr., T. M. Murray, M. Peacock, H. D. Niall, G. W. Tregear, H. T. Keutmann, D. Powell, and L. J. Deftos. 1971. Parathyroid Hormone: Sequence, synthesis and immunoassay studies. Am. J. Med. 50: 639 .

14. Deftos, L. J. 1971. Immunoassay for human calcitonin. I. Method. Metab. (Clin. Exp.). 20: 1122.

15. Deftos, L. J., A. E. Bury, G. P. Mayer, J. F. Habener, F. R. Singer, D. Powell, L. Crook, E. Watts, and J. T. Potts, Jr. 1972. Radioimmunoassays for calci- tonins: clinical and experimental studies. In Endocrinology. Proceedings of the Third International Symposium. S. Taylor, editor. Heineman Ltd., London. 89.

16. Lee, M. R., L. J. Deftos, and J. T. Potts, Jr. 1969. Control of secretion of thyrocalcitonin in the rabbit as evaluted by radioimmunoassay. Endocrinology. 84: 36.

17. Deftos, L. J., J. F. Habener, G. P. Mayer, A. E. Bury, and J. T. Potts, Jr. 1972. Radioimmunoassay for bovine calcitonin. J. Lab. Clin. Med. 79: 480.

18. Colt, E. W. D. L. E. M. Miles, K. L. Becker, and N. J. Shah. 1971. A sensitive new immunoassay for calcitonin employing labeled antibody. J. Clin. Endocrinol. Metab. 32 : 285.

19. Arnaud, C. D., T. Littledyke, H. S. Tsao, and E. L. Kaplan. 1968. Radioimmunoassay of calcitonin: a preliminary report. Mayo Clin. Proc. 43: 496.

20. Sizemore, G. W., V. L. W. Go, E. L. Kaplan, L. J. Sanzenbacher, K. H. Holtermuller, and C. D. Arnaud. 1973. Relations of calcitonin and gastrin in ZollingerEllison Syndrome and medullary carcinoma of thyroid. N. Engl. J. Med. 288 : 641 .

21. Arnaud, C. D., T. Littledyke, and H. S. Tsao. 1969. Calcium homeostatis and the simultaneous measurement of calcitonin and parathyroid hormone in the pig. In Calcitonin. S. Taylor and G. Foster, editors. Heinemann Ltd., London. 95.

22. Gittes, R. F., S. V. Toverud, and C. W. Cooper. 1968. Effects of hypercalcemia and hypocalcemia on the thyrocalcitonin content of rat thyroid glands. Endocrinology. $82: 83$.

23. Hennessey, J. F., T. K. Gray, C. W. Cooper, and D. A. Ontjes. 1973. Stimulation of thyrocalcitonin secretion by pentagastrin and calcium in two patients with medullary carcinoma of the thyroid. J. Clin. Endocrinol. Metab. 36: 200. 